\title{
The Determinants that Influence Household Debt Case in Malaysia
}

\section{Nur Azwani Mohamad Azmin, Wan Nabihah Wan Zaidi, and Zuraida Mohamad}

Faculty of Business and Management, Universiti Teknologi MARA, Dungun, Terengganu, Malaysia

\section{Abstract}

The level of household debt in Malaysia may in turn cause another financial crisis as it is at worrying stage. Therefore, the aims of this study is to identify the relationship between household debt and its determinants as well as to determine the most significant factor that affect the household debt. The mode of empirical investigation is Ordinary Least Square Method with the multiple regressions which are applied to monthly time series data spanning from 2012 to 2016 for four variables such as Interest Rate, Inflation, Unemployment Rate and Consumption. Data collected from Eikon Thomson Reuters and Monthly Statistical Bulletin. The study implies that interest

Corresponding Author: Nur Azwani Mohamad Azmin nurazwani@tganu.uitm.edu.my

Received: 10 February 2019 Accepted: 14 March 2019 Published: 28 March 2019

Publishing services provided by Knowledge E

(c) Nur Azwani Mohamad Azmin et al. This article is distributed under the terms of the Commons Attribution License, which permits unrestricted use and redistribution provided that the original author and source are credited.

Selection and Peer-review under the responsibility of the ICIEBP Conference Committee.

\section{G OPEN ACCESS} rate, unemployment rate and consumption are positive and significantly related with household debt whereas the result illustrates an insignificant yet positive relationship between inflation and household debt. As a conclusion, these findings bear important implications for Malaysian policymakers.

Keywords: Interest Rate, Inflation, Unemployment Rate and Consumption.

\section{Introduction}

Household debt is defined as household that requires payment or payments of interest or principal to the creditor at a date or dates in the future for all the liabilities. Households borrow for several reasons such as need a long period of saving and deferred consumption by borrowing to purchase a home. Therefore, debt can make resource allocation more efficient and improve living standards by bringing forward consumption and investment.

Despite from that, an increase in household borrowing shows serious matter because it does not always good for individual household or for the sector as whole. Then, according to the experience in a number of countries during the global financial crisis, the risk of financial crises and economic instability can materially increase as level of 
household debt increase. High private debt can have a big negative impact on macroeconomic performance and stability. The ability of households to smooth consumption and effects investment of corporations will be barrier.

In a nut shell, understanding the effect of household indebtedness on the sensitivity of aggregate expenditure to shock is relevant not only for macroeconomic stability but also for financial stability. Households need to find any initiative in order to cope with the problem before it getting worse. For example, households learn how to manage their debt wisely according to their ability and income to make any loans. Thus, household debt can be stand at stable stage and manageable.

\section{Literature Review}

\subsection{Household debt}

The increasing household debt has attracted the attention of economic analysts, academicians and policy makers to investigate about the household debt in more details. Besides that it will gives a negative impact and creates vulnerabilities to the financial stability when the level of household debt is high (Charpe \& Flaschel, 2013).

There are many studies use different variables like interest rate (Hafizah et. al, 2016; Sharezan \& Mansur, 2014; Meng et. al, 2013; Mutezo, 2014; Hoang \& Meng, 2015; Masturah et. al, 2016; Zimunya \& Raboloko, 2015 and Catherine et. al, 2016), housing prices (Hafizah et. al, 2016; Hoang \& Meng, 2015; Nomatye \& Phiri, 2017; Meniago et. al, 2013 and Masturah et. al, 2016), consumption (Catherine et. al, 2016; Nomatye \& Phiri, 2017; Meniago et. al, 2013; Nurulhuda, 2015 and Zimunya \& Raboloko, 2015), gross domestic product (Sharezan \& Mansur, 2014; Meng et. al, 2013; Hoang \& Meng, 2015; Masturah et. al, 2016 and Nomatye \& Phiri, 2017) and many more. Hence, this study chooses to use interest rate, inflation, unemployment rate and consumption as the independent variables by monthly basis using time series data.

Some methods were used in several studies are Ordinary Least Squared (Masturah et. al, 2016 and Jauch \& Watzka, 2013), Vector Error Correction Model (Meniago et. al, 2013; Sharezan \& Mansur, 2014 and Zimunya \& Raboloko, 2015), Autoregressive Distributed Lag Model (Hafizah et. al, 2016 and Nurulhuda, 2015) and more other methods (Meng et. al, 2013; Mutezo, 2014; Anderson et. al, 2014; Hoang \& Meng, 2015; Catherine et. al, 2016 and Nomatye \& Phiri, 2017).

In other perspective, many researchers study on the household debt were using differing in terms of countries. Some researches studies in the case of Malaysia (Hafizah 
et. al, 2016; Masturah et. al, 2016; Sharezan \& Mansur, 2014 and Nurulhuda, 2015). For the studies that are conducted in South Africa (Mutezo, 2014), in Australia (Hoang \& Meng, 2015) and others countries (Meng et. al, 2013; Meniago et. al, 2013; Jauch \& Watzka, 2013; Anderson et. al, 2014; Zimunya \& Raboloko, 2015; Catherine et. al, 2016 and also Nomatye \& Phiri, 2017).

\subsection{Interest rate}

Interest rate is the amount charged and can be measured as a percentage of principal, by a lender to a borrower for the use of assets. This variable is supported by many previous researchers.

Interest rate can be either positively or negatively impact on household debt based on different research approaches. Interest rate can be positive relationship with household debt as higher interest rate will influence more housedebt (Anderson et. Al, 2014; Zimunya \& Raboloko, 2015; Hafizah et. Al, 2016 and Catherine et. Al, 2016). Anderson et. al (2014) as well as Zimunya and Raboloko (2015) discover that interest rate has positive and significantly affect household debt which used the survey and vector error correction model respectively. Meanwhile, the result by Zimunya and Raboloko (2015) suggest interest rates also have significant influence on household debt. Hafizah et. al (2016) investigated about modelling the determinants of Malaysian household debt and found that interest rate has positive significant relationship with the changes of household debt. Study done by Catherine et. al (2016) also agreed that interest rate is positive significant with household debt because when the economy is performing well, interest rate and consumer spending increases resulting in higher household debt.

Apart from that, some studies also found that interest rate is negative and significant in influencing household debt (Meng et. al, 2013; Hoang \& Meng, 2015; Nurulhuda, 2015; Nomatye \& Phiri, 2017 and Masturah et. al, 2016). Interest rate also plays a crucial role in the study about the determinants of Australian household debt, a macro level study since it is the most significant and negatively relationship Therefore, quarterly time series data from 1988Q2 to 2011Q2 is used to test the rising Australian household debt (Meng et. al, 2013). Masturah et. al. (2016) also have similar result obtained that interest rate is negatively significant relationship with household debt. All the authors stated that because they found valid reason is that a rise of interest rate will also increase cost of borrowing. Therefore, households will reduce the amount of money they want to borrow and also may delay their intent to borrow. 
However, there are some studies found that the interest rate is insignificant effect on household debt. The study conducted by Sharezan and Mansur (2014) and Mutezo (2014) claimed that interest rate shows insignificant related to household debt by using time series technique. The study investigated the relationship between household debt and consumption spending in South Africa for the period of 1986-2013 by using modern econometric techniques.

\subsection{Inflation rate}

Inflation refers to the rate at which the general level of prices for goods and services is rising hence the purchasing power of currency is falling. This variable has been seen reported by Meng et. al (2013), Mutezo (2014), Zimunya and Raboloko (2015), Catherine et. al (2016) and Nomatye and Phiri (2017).

Furthermore, inflation has positive and significant in influencing household debt which is supported only by Mutezo (2014). The reason is when interest rate is being cleverly controlled by the reserve bank in the event of inflation going up, South Africa households will be burdened by debts that they will not be able to pay.

Contradict with the study above, inflation also can be negative and significant related to the household debt (Meng et. Al, 2013 and Catherine et. al, 2016). They argued that higher inflation would reduce the household's ability to borrow. With regard to borrowing, inflation will devalue the debt, providing a strong stimulus for households to borrow.

Then inflation also can be found insignificantly related to the household debt. Nomatye and Phiri (2017) applied that inflation have insignificantly relationship with the household debt by investigating the macroeconomic determinants of household debt in South Africa. Other study done by Zimunya and Raboloko (2015) also stated that inflation is insignificantly related to the household debt. By adding the inflation premium to real interest rates, the tendency of inflation to stimulate demand for credit is cancelled out by the increase in the nominal interest rates hence the net effect of inflation is not significant (Zimunya \& Raboloko, 2015).

\subsection{Unemployment rate}

Unemployment rate refers as the number of unemployed people as a percentage of the labour force, where the latter consists of the unemployed plus those in paid or self-employment. Some researchers study the relationship of unemployment rate and 
household debt which are Meng et. al (2013), Jauch and Watzka (2013), Hoang and Meng (2015), Catherine et. al (2016) and Masturah et. al (2016).

Therefore, unemployment rate can be positively related to the household debt. Jauch and Watzka (2013) investigated the effect of household deleveraging on unemployment in Spanish and found that an increase in household debt was found to be significantly affected by positive changes in unemployment. In a different study, Catherine et. al (2016) revealed that unemployment rate is positive and significant relationship with household debt because they found that temporary unemployment situation would also compel households to increase debt when they have to maintain their current living standards.

As different from above paragraph, unemployment rate also has negative and significant relationship on household debt (Meng et. al, 2013; Hoang and Meng, 2015 and Masturah et.al, 2016). A study by Meng et. al (2013) about the determinants of Australian household debt suggests unemployment rate is one of the leading factors which explains rising household debt level in Australia. Defaults on payments will occur as borrowers will find it difficult to maintain their mortgage payments during periods of unemployment (Hoang \& Meng, 2015).

\subsection{Consumption}

Consumption also is one of the factors that affect on household debt done by Meniago et. al (2013), Nurulhuda (2015), Zimunya and Raboloko (2015) Catherine et.al (2016), and Nomatye and Phiri (2017).

Consumption could be expected to have a positive and significant effect on household debt which has similar result with (Meniago et. al, 2013 and Zimunya \& Raboloko, 2015). Beginning with the study of Meniago et. al (2013) who examine what causes household debt to increase in South Africa and the result also found that household consumption has positive and significant relationship with household debt. This finding confirms what was expected from the theory and this tells us that in South Africa, the more households increase their consumption, the more they go into large amounts of debt. Moreover, encouraging financial literacy among individuals would help households make informed decisions as they allocate their income between their consumption and saving.

On the other hand, consumption can be negative and significant relationship with household debt. This result was supported by Nurulhuda (2015) and Catherine et. al 
(2016). These researches propose that household need to reduce consumption and some may even resort to debt when they are facing difficulties.

Last but not least, insignificant relationship also can be related between consumption and household debt. Thus only one study done by Nomatye and Phiri (2017) agreed with the expectation result. The observation from Nomatye and Phiri (2017) provides a very informative discussion of investigating the macroeconomic determinants of household debt in South Africa.

\section{Methodology}

The dependent variable for this study is Household Debt (HD) and the independent variables are Interest Rate (IR), Inflation Rate (INF), Unemployment Rate (UR) and Consumption (CONS). The data of these variables are secondary data and time series data which obtained from Eikon Thomson Reuters and Monthly Statistically Bulletin. In addition, this study also used sample data period from 2012 to 2016 on a monthly basis while method used to interpret the data in this study is using Ordinary Least Square (OLS) method. At first, correlation analysis will be conducted to find the correlation between dependent variable and independent variables, and to detect the multicollinearity problem in the regression. Durbin-Watson test is conducted to detect the problem of autocorrelation. The regression equation as below:

$$
H D=-\alpha+\beta_{1} I R+\beta_{2} I N F+\beta_{3} U R+\beta_{4} \operatorname{LCONS}+\mu
$$

where:

$$
\begin{aligned}
& \mathrm{HD}=\text { Household Debt } \\
& \mathrm{IR}=\text { Interest Rate } \\
& \mathrm{INF}=\text { Inflation } \\
& \text { UR }=\text { Unemployment Rate } \\
& \text { LCONS = Consumption } \\
& \beta_{1,2,3,4}=\text { coefficient value } \\
& \mu=\text { error term }
\end{aligned}
$$

\section{Result}




\subsection{Correlation analysis}

Correlation is statistical measure that indicates the extent to which to two or more variables fluctuate together.

TABLE 1: Correlation Analysis.

\begin{tabular}{|l|l|l|l|l|l|}
\hline & HD & IR & INF & UR & LCONS \\
\hline HD & 1.000 & & & & \\
\hline IR & 0.686 & 1.000 & & \\
\hline INF & 0.148 & 0.141 & 1.000 & & \\
\hline UR & 0.622 & 0.159 & -0.157 & 1.000 & \\
\hline LCONS & 0.903 & 0.658 & 0.145 & 0.539 & 1.000 \\
\hline
\end{tabular}

A positive correlation indicates the extent to which does variables increase or decrease in parallel. A negative correlation indicates the extent to which one variables increase as the other decrease. Generally, correlation among independent variables is not a serious problem as the result shown is less than 0.8 .

Based on the Table 1, it reveals that all independent variables (IR, INF, UR, and LCONS) have positive correlated with the dependent variable (HD). It shows that when household debt is increasing, all the independent variables also increasing and vice versa.

Correlation analysis also can be used to detect multicollinearity problem. The result reveals that there is no multicollinearity problem as the number correlation for all variables are less than 0.8 .

\subsection{Regression model}

For the final estimation model, the model can be developed as equation below:

$$
H D=-148.99+6.22^{* * *} I R+0.27 I N F+3.61 U^{* * *}+9.14 \text { LCONS}^{* * *}
$$

where:

$$
\begin{aligned}
& \mathrm{HD}=\text { Household Debt } \\
& \mathrm{IR}=\text { Interest Rate } \\
& \mathrm{INF}=\text { Inflation } \\
& \text { UR = Unemployment Rate } \\
& \text { LCONS = Consumption }
\end{aligned}
$$


TABLE 2: Linear Multiple Regression Analysis.

\begin{tabular}{l|c|c|c}
\hline Variables & Coefficient & t-Statistic & Probability \\
\hline C & -148.9684 & -7.180336 & 0 \\
\hline IR & 6.222944 & 3.887502 & $0.0003^{* * *}$ \\
\hline INF & 0.268854 & 1.494378 & 0.1408 \\
\hline UR & 3.610641 & 4.66883 & $0.0000^{* * *}$ \\
\hline LCONS & 9.14218 & 7.241098 & $0.0000^{* * *}$ \\
\hline & & & Durbin-Watson \\
\hline R-squared & & F-statistic & 1.525329 \\
\hline 0.878563* & 99.47786 & \\
Note: ${ }^{* * *},{ }^{* *},{ }^{*}$ denotes the significance level of variables at $1 \%, 5 \%$ and $10 \%$ respectively.
\end{tabular}

Based on the result in Table 2, R-squared for this study is 0.8786 and it revealed that $87.86 \%$ of the variation in dependent variable (household debt) can be explained by all independent variables (interest rate, inflation, unemployment rate and consumption). Only $12.14 \%$ cannot be explained. From this study, F-statistic is above than the F-critical which is 99.48 where it is higher than four is significant at $1 \%$ significance level. Thus it showed that the independent variables as a whole are statistically significant in influencing dependent variables. The result from this study of the Durbin Watson is 1.53 and it is not between the rule of thumb which is between the ranges of $1.8-2.2$. Thus, autocorrelation problem exists.

As per result, three variables have shown significant relationships with household debt and only for inflation rate is not significant. Interest rate, unemployment rate and consumption have positive and significant relationship with household debt at 1 percent significance level. Meanwhile inflation has positive but insignificant relationship with household debt.

From the Equation 2, the value -148.97 represent the constant variables for this study. If other variables are held constant, household debt will decrease by 148.97 .

Based on the result obtained in this study, it revealed that interest rate has positive relationship towards household debt at 1 percent significant level. The positive coefficient shows that as the interest rate increases by 1 percent, household debt will increase by 6.22 units. This is in line with the findings of Anderson et. al (2014), Zimunya and Raboloko (2015), Catherine et. al (2016) and Hafizah et. al (2016) who studied the relationship between household debt and interest rate. The result revealed that the relationship is positive significant because when the economy is performing well, interest rate and consumer spending increases resulting in higher household debt. 
This positive relationship result is matched with the expected sign. However, this result contradicts with the studies done by Meng et. al (2013), Hoang and Meng (2015) and Masturah et. al (2016) which said that interest rate has negative relationship because the valid reason is a rise in interest rate will also increase cost of borrowing. Therefore, households will reduce the amount of money they want to borrow and also may delay their intent to borrow.

Furthermore, unemployment rate has a positive and significant relationship with household debt at 1 percent significant level as shown from the above equation. The findings found that with an increase in unemployment rate by 1 percent, household debt will increase by 3.61 units where it is matched with the expected sign. This can be supported by previous researchers which include Jauch and Watzka (2013) and Catherine et. al (2016). All the studies stated that unemployment rate is positive and significant relationship between household debts which is consistent with this result. They conclude that unemployment situation would also lead household to increase debt when they have to maintain for their living standards. Apart from that, this result opposes studies done by Meng et. al (2013), Hoang and Meng (2015) and Masturah et. al (2016) which claimed that unemployment rate has negative relationship with household debt. They implying that default on payments will occur as borrowers will find it difficult to maintain their mortgage payments during periods of unemployment.

Other than that, the consumption also has parallel relationship like interest rate and unemployment rate where it has positive and significant relationship with the household debt. This is also the same result as expected sign. It can be seen by 1 million increase in consumption will increase by 9.14 units of household debt. The outcome for this study is matched and can be supported by Meniago et. al (2013) and Zimunya and Raboloko (2015). Therefore, those studies found that the greater the consumption, the greater the household debt. According to that, this will encourage households to borrow more and in response household debt to increase. Meanwhile, there are inconsistent results from this study which are done by Nurulhuda (2015), Catherine et. al (2016) and Nomatye and Phiri (2017). They indicated that the higher the consumption, the lower the household debt because they found that when households are facing difficulties, they need to reduce consumption and some may lead to use debt.

This result also shows that there is a positive relationship between inflation and household debt in Malaysia, but this relationship was shown to be statistically insignificant. As the inflation increase by 1 percent, household debt will increase by 0.27 units which also can be obtained from the positive coefficient. This result has been approved by the study done by Nomatye and Phiri (2017) and Zimunya and Raboloko (2015). The 
reason is when interest rate is being cleverly controlled by the reserve bank in the event of inflation going up, South Africa households will be burdened by debts that they will not be able to pay. Both studies had agreed that inflation has insignificant relationship with household debt which is contradict with the expected sign. On the other hand, according to Meng et. al (2013) and Catherine et. al (2016) were found that inflation has negative relationship in influencing household debt. This is because when face of high inflation, fewer funds is lent and household debt will decrease.

Last but not least, all of the variables were found to be important in explaining household debt in Malaysia except only for inflation which shown not significant. Interest rate, unemployment rate and consumption have positive and significant relationship household debt while inflation was found to have positive and insignificant relationship with household debt. In this study also shows that consumption is the most significant factor that influencing the household debt due to the highest T-statistic value of 7.2411 as compared to other factors.

\section{Conclusion}

As a conclusion, this paper studies about the determinants of household debt in Malaysia Moreover, the aims of this study are to identify the relationship between household debt and its determinants and to determine the most significant factors that affect the household debt. The selected macroeconomic variables are interest rate, inflation, unemployment rate and consumption.

According to the findings obtained in this study, the objectives for this study have been achieved and it is able to answer all research questions provided. The result obtained that interest rate, unemployment rate and consumption has positive and significant relationship with household debt at $1 \%$ significant level. Meanwhile, positive and insignificant relationship with household debt is shows by inflation. The interest rate, unemployment rate and consumption are matching with the expected result while only inflation is contradicted with the expected. Besides that, this study has proved that the consumption is the most significant variable in influencing the household debt as compared to the other variables. This is because the value of t-statistic shows the highest value which is 7.2411 .

Overall, this study also done to investigate the relationship between dependent variable and independent variable as well as to identify the most significant factors affect on household debt. All variables such as interest rate, unemployment rate and consumption have been proved that it has positive and significant relationship with 
household debt while inflation has a positive yet insignificant relationship. It is also proved that consumption is the most significant variable in influencing household debt in Malaysia. Thus, the objective, research question and hypothesis have been answered and explained clearly in this study.

\section{References}

[1] Anderson, G., Bunn, P., Pugh, A., \& Uluc, A. (2014). The potential impact of higher interest rates on the household sector: evidence from the 2014 NMG Consulting survey.

[2] Catherine S. F. H., Jamaliah M.Y., Aminah M. \& Arshad A. (2016). Household Debt, Macroeconomic Fundamentals and Household Characteristics in Asian Developed and Developing Countries. The Social Sciences, Vol.11, p4358-4362.

[3] Charpe, M., \& Flaschel, P. (2013).Workers' debt, default and the diversity of financial fragilities. StructuralChange and Economic Dynamics, 27, 48-65. Retrieved from https://pdfs.semanticscholar.org/fa9b/7595ec6e2074c185cb40c1d4149dac4

[4] Hafizah H. A. K, Hussin A. Shamzaeffa S. (2016). Modelling the Determinants of Malaysian Household Debt. International Journal of Economics and Financial Issues, 6(4).

[5] Jauch, S., \& Watzka, S. (2013). The Effect of Household Debt Deleveraging on Unemployment-Evidence from Spanish Provinces.

[6] Masturah M., Amira I. \& Badariah (2016). Household Debt and Macroeconomic Variables in Malaysia. 3rd International Conference on Business and Economics. Retrieved from http://dx.doi.org/10.15405/epsbs.2016.11.02.12

[7] Meniago, C., Petersen, J.M., Petersen, M. A., \& Mongale, I. P. (2013). What causes household debt to increase in South Africa?. Economic Modelling, 33, 482-492.

[8] Meng X., Hoang N. T., Siriwardana. (2012). The determinants of Australian household debt: A macro level study. Journal of Asian Economics.

[9] Mutezo, A. (2014). Household debt and consumption spending in South Africa:an ARDL-bounds testing approach. Banks and Bank Systems, Vol 9.

[10] Hoang, N., \&Meng, S. (2015). The Rising Australian Household Debt: Results from A Bayesian VAR Analysis. Unpublished paper. Retrieved from https://www.uml.edu/ docs/Housing_Paper_tcm18-154277.pdf

[11] Nomatye A., Phiri A, (2017). Investigating the macroeconomic determinants of household debt in South Africa. Munich Personal RePEc Archive. 
[12] Nurulhuda, N. (2015). Determinants Of Malaysia Household Debt: Macroeconomic Perspective. Proceeding - Kuala Lumpur International Business, Economics and Law Conference 6, Vol. 1. Retrieved from http://www.futureacademy.org.uk/files/images/ upload/11_Beci2016.pdf

[13] Sharezan A. R. \&Mansur M. (2014). Increasing household debts and its relation to GDP, interest rate and house price: Malaysia's perspective. Munich Personal RePEC Archive, No. 62365. Retrieved from https://mpra.ub.uni-muenchen.de/62365/

[14] Zimunya, F. M., \&Raboloko, M. (2015). Determinants of household debt in Botswana: 1994-2012. Journal of Economics and Public Finance, 1(1), 14. 